\title{
Effects of Direct Sowing under Mulch-Based Cropping System (DMC) on Cotton and Maize Yield and Chemical Characteristics of Ferruginous Soil (Lixisoil) in the South Sudan Area of Burkina Faso
}

\author{
Adama Ouattara1*, Bazoumana Koulibaly¹, Déhou Dakuo1, Kalifa Coulibaly², Pascal Bazongo³, \\ Oula Traore ${ }^{4}$, Hassan Bismarck Nacro²
}

${ }^{1}$ Institute of Environment and Agricultural Research (INERA), Bobo-Dioulasso, Burkina Faso

${ }^{2}$ Laboratory for Soil Fertility Studies and Research, Nazi BONI University, Bobo-Dioulasso, Burkina Faso

${ }^{3}$ University of Fada N'Gourma, Fada N'Gourma, Burkina Faso

${ }^{4}$ West African Monetary Economic Union (UEMOA), Ouagadougou, Burkina Faso

Email: *adamaouatt30@gmail.com

How to cite this paper: Ouattara, A., Koulibaly, B., Dakouo, D., Coulibaly, K., Bazongo, P., Traore, O. and Nacro, H.B. (2021) Effects of Direct Sowing under Mulch-Based Cropping System (DMC) on Cotton and Maize Yield and Chemical Characteristics of Ferruginous Soil (Lixisoil) in the South Sudan Area of Burkina Faso. Open Journal of Soil Science, 11, 352-365.

https://doi.org/10.4236/ojss.2021.116018

Received: March 23, 2021

Accepted: June 27, 2021

Published: June 30, 2021

Copyright ( 2021 by author(s) and Scientific Research Publishing Inc. This work is licensed under the Creative Commons Attribution-NonCommercial International License (CC BY-NC 4.0). http://creativecommons.org/licenses/by-nc/4.0/ (c) (i) (8) Open Access

\begin{abstract}
To better understand the effects of direct sowing under mulch-based cropping system (DMC) in Burkina Faso's cotton production systems, randomized blocks of Fisher experimental design were implemented at Farako-Bâ research station from 2010 to 2019. The study was conducted on lixisoil to evaluate DMC effects on biomass production, crops yields and soil chemical properties in a maize and cotton rotation system associated with cover crop. Conventional tillage and direct seeding without cover crop were compared to DMC under B. ruziziensis (GERM. \& EVRARD), DMC under B. ruziziensis + $M$. cochinchinensis mulch and DMC under $C$. juncea (L.) mulch used in association with maize. Biomass production, crop yields and soil chemistry were evaluated. Results showed that over 10 years, no-till with or without a cover crop provided cotton seed and maize yields that were statistically equivalent to the tillage commonly practiced by farmers. Cover crop has allowed increasing the biomass production compared to Conventional Tillage and Direct Seeding. Maize yield has not varied significantly with the cover crop. After 10 years of maize and cotton rotation, the improvement raised from $+27 \%$ to $+38 \%$ for organic matter and from $+15 \%$ to $+29 \%$ for nitrogen with DMC including legumes such as $M$. cochinchinensis and $C$. juncea compared to Conventional Tillage on $0-5 \mathrm{~cm}$ depth. No significant differences were found on soil $\mathrm{pH}$ like $\mathrm{P}_{2} \mathrm{O}_{5}$ and $\mathrm{K}_{2} \mathrm{O}$ content. Although DMC with $C$. juncea
\end{abstract}


used as cover crop did not provide the best biomass production, it contributes to increase nitrogen and organic matter and presents better mineral balances in 10 years of rotation. The $5-10 \mathrm{~cm}$ and $10-20 \mathrm{~cm}$ were little influenced by DMC systems.

\section{Keywords}

Cover Crop, Tillage, Direct Sowing under Mulch-Based Cropping System, Crop Rotations, Soil Characteristic, Leguminous

\section{Introduction}

To be adopted in terms of inadequate crop systems [1]. Many Conservation agriculture (CA) has long been practiced around the world [2]. In Burkina Faso, as in some sub-Saharan African countries, several studies have been conducted on the socio-economic benefits and positive water balance of CA and have allowed some researchers to recommend this form of agriculture [3]. However, the contribution of CA on physical, chemical and biological characteristics will constitute arguments for better adoption of CA for sustainable production [4] [5]. It's characterized by three principles: minimum tillage, and soil disturbance permanent soil cover and crop rotation and intercropping [5]. CA exists in several forms. From reduced tillage alone or in combination with cover crops, it can ensure sustainable production. In direct sowing under mulch-based cropping system (DMC) which is a form of conservation agriculture, cotton production takes on another dimension because the fiber cannot be associated with biomass production that could influence its quality. In West African cotton systems, soil fertility constitutes a major constraint on ensuring sustainable production [3]. Extension of crop areas is not possible due to over increasing of the human population. The dynamics of agro-systems and soil fertility management in West Africa have led to negative soil evolution. As a result, the acidity, the organic matter and mineral content in soils are below the average recommended levels according to soil chemical interpretation standards [6] [7]. Cropping systems must focus on maintaining or improving the soil organic matter and mineral content and their availability for crops. Factors that contribute to soil degradation include the lack of organic restitution, cropping practices such as annual ploughing of fields [6] [8]. However, DMC application in cotton-based production systems requires an adaptation of the principles in order to ensure cereals and cotton production that meets market standards. Crop residues are insufficient for good soil cover in sub-Saharan Africa [9]. It is important to use cover plants in combination with cereals in a context of cropland scarcity to improve the amount of biomass on plots. In direct sowing under mulch-based cropping system (DMC), cover plants are used based on their highly variable characteristics from one species to another [10].

Depending on their characteristics and their development mode, cover crops 
can influence soil characteristics in different ways. B. ruziziensis has high potential to produce above and below ground biomass that can reach deep soil layers. $C$. juncea is a dicotyledon plant with high biomass, which allows mineral elements to be brought up into surface layers. $M$. cochinchinensis is a creeping leguminous with important biomass.

Therefore, it is necessary to identify the contributions of cover plants species, including their potential for producing aerial and underground biomass that may improve soil fertility. In DMC the chemical characteristics of the soil, namely organic matter, nitrogen, phosphorus, and potassium contents, are thought to be partly the result of cover plants and the roots biomass decomposition [11]. The residues degradation in the soil is a function of climate, soil characteristics and residues quality. The degradation rate of mulch depends on the organic matter quality. The quantity and quality of biomass produced varies according to the cover crop species [12]. In the DMC, this degradation constitutes an important source to improve nitrogen, phosphorus and potassium rate of soil. In addition to their biomass production potential, some cover plants are atmospheric nitrogen-fixing. Many cover plants as Brachiaria spp., Panicum spp., dicotyledon, namely Crotalaria spp. Cajanus spp. and Mucuna spp. are using by the farmers [13]. The objective of this study is to determine the effects of DMC with three specifics covers crops, on the crops yields and chemical characteristics of soil in the South Sudan area of Burkina Faso.

\section{Methods}

\subsection{Study Site}

The experimental site was located at Farako Bâ research station in a southwest of Bobo Dioulasso. From 2009 to 2019, the annualmean rainfall was between 744 $\mathrm{mm}$ received in 51 days and $1308 \mathrm{~mm}$ in 72 days (Figure 1). Compared to the mean, 2010, 2013, 2014, 2018, and 2019 rainy seasons recorded an increase from 58 to $239 \mathrm{~mm}$ of water. The lowest rainfall was recorded in 2011 and 2017 with 831 and $744.6 \mathrm{~mm}$ respectively (Figure 1). The soil studied is lixisol characterized by low organic matter (less than 1\%), total $\mathrm{N}(0.043 \%)$ and $\mathrm{P}\left(104.43 \mathrm{mg} \cdot \mathrm{kg}^{-1}\right)$

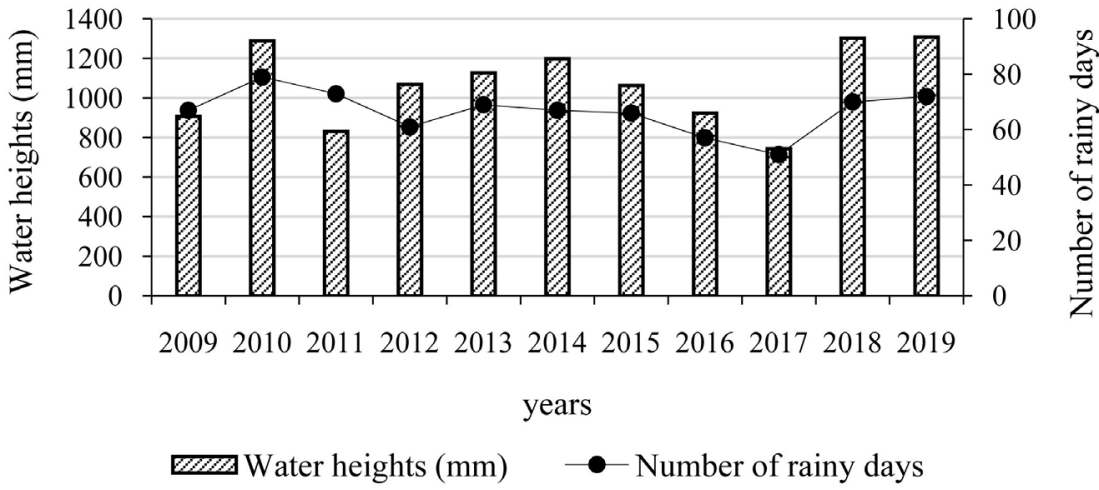

Figure 1. Annual rainfall of Farako-Bâ research station from 2009 to 2019. 
content. Texture was sandy in $0-40 \mathrm{~cm}$ depth and clay in 40 to $60 \mathrm{~cm}$ depth. The $\mathrm{pH}$ varied from 5.3 to 5.6 .

\subsection{Plant Materiel}

Plant material used included maize (Zea mays L.) variety SR21 with 95 - 110 days of cycle (seeding to maturity) and $5100 \mathrm{~kg} \cdot \mathrm{ha}^{-1}$ as potential yield and the cotton (Gossypium hirsutum L.) FK37 with 120 days of cycle (seeding to boll opening) and $2600 \mathrm{~kg} \cdot \mathrm{ha}^{-1}$ as potential yield. These varieties are adapted to the local conditions and comely used in Burkina Faso. Three species of cover plants used in pure or in combination with other crops. The biomass of B. ruziziensis (GERM. \& EVRARD) can reach 6000 to $8000 \mathrm{~kg} \cdot \mathrm{ha}^{-1}$ under tropical climate. Its fasciculate root system is made up of many roots, dense and constitutes an important source of organic matter both on the surface and in the depth from 1.8 $\mathrm{m}$ to $2 \mathrm{~m}$ and can help to improve soils [13]. The root system is capable to restructure soil, bring carbon in depth and recycling leached nutrients.

$M$. cochinchinensis is a leguminous used as green manure and cover plant species, is also grown in combination with cereals to improve biomass. As leguminous, $M$. cochinchinensis fixes atmospheric nitrogen. The $C$. juncea $(L$.) is an annual leguminous up to $4 \mathrm{~m}$ long. Its potential biomass can reach 3 to $6 \mathrm{t} \cdot \mathrm{ha}^{-1}$ with $3.6 \%$ of nitrogen. It can return 100 to 220 units of nitrogen per hectare (Notice: les crotalaires from Institut technique tropical). The maize, cotton and $M$. cochinchinensis seeds were provided by the seed production service at the Farako-Bâ experimental research center. The seeds of B. ruziziensis and C. juncea were provided by Brazilian Agricultural Research Company, Secretariat of International Relations (Embrapa Cotton).

\subsection{Soil Fertilization}

Inorganic fertilizer $(14-18-18+6 \mathrm{~S}+1 \mathrm{~B})$ were applied in side dressing ten centimeters from the roots and buried at the rate of $44 \mathrm{~N}, 27 \mathrm{P}, 27 \mathrm{~K}, 9 \mathrm{~S}$ and $1.5 \mathrm{~B}$ per hectare on cotton and $74 \mathrm{~N}, 36 \mathrm{P}, 36 \mathrm{~K}, 12 \mathrm{~S}$ and $2 \mathrm{~B}$ per hectare on maize at 15 days after sowing and Urea ( $46 \%$ of $\mathrm{N})$ at 40 days after sowing

Five treatments including three direct sowing under mulch-based cropping system (DMC) with cover plants associated with maize was compared and defined below:

- Conventional Tillage (CT) (annual ploughing): cotton/maize sowing after annual plough;

- Direct Seeding (DS) without cover plant: direct sowing of cotton/maize without mulch;

- DMC/B. ruziziensis mulch (DMC 1): direct sowing of cotton under maize and B. ruziziensis mulch;

- DMC/B. ruziziensis + M. cochinchinensis mulch (DMC 2): direct sowing of cotton under maize and $B$. ruziziensis $+M$. cochinchinensis mulch;

- DMC/C. juncea mulch (DMC 3): direct sowing of cotton under maize and $C$. juncea mulch. 


\subsection{Methodological Approach}

The approach adopted in this study is to define the possibilities of biomass production with the use of cover plants associated with maize in cotton and maize biennial rotation systems. The growing of maize and cover plants provides a biomass for the direct seeding of the cotton the following campaign. On the course of this study, a randomized block of Fisher experimental design with five treatments and four replications was used for this study. The basic plot consists of 11 lines of $20 \mathrm{~m}$.

Maize, cover crops and cotton residues are kept on the plots. At the head of rotation, maize is combined with cover crops to improve biomass production for use as soil cover. After 15 to 20 days of maize sowing, B. ruziziensis and C. juncea were sown continuously between the maize rows and $M$. cochinchinensis is sowing in pocket $(0.40 \mathrm{~m}$ between pockets). Cotton and maize were sown at the same dimensions, i.e. $0.80 \mathrm{~m}$ between rows and $0.40 \mathrm{~m}$ between pocket, giving 62,500 plants $\mathrm{ha}^{-1}$ as theoretical density.

NPKSB fertilizer was applied 15 days after emergence and urea at 40 days after emergence. Weed control was carried out if necessary and phytosanitary treatments were carried out using Indoxacarb $150 \mathrm{~g} \cdot \mathrm{L}^{-1}$, Zeetacypermethryn $12 \mathrm{~g} \cdot \mathrm{L}^{-1}$ profenfos $200 \mathrm{~g} \cdot \mathrm{L}^{-1}$ and Acetamiprid $32 \mathrm{~g} \cdot \mathrm{L}^{-1}$ cypermethrin $144 \mathrm{~g} \cdot \mathrm{L}^{-1}$ for the three insecticide treatment windows. Maize combined with cover crops was sown in 2010, 2012, 2014, 2016 and 2018, while cotton was sown in 2011, 2013, 2015, 2017 and 2019.

\subsection{Data Collection and Analysis}

The variables studied consisted of the biomass of maize and cover plant, changes in crop yields, soil acidity $(\mathrm{pH})$, soil organic matter levels, $\mathrm{P}$ total and available $\mathrm{P}$, total $\mathrm{K}$ and available $\mathrm{K}$. The balances of the chemical parameters were assessed from the initial soil reserves to the implementation of the test and the reserves after 10 years of application of the different systems. The balance sheets reflect the amount between the soil reserves in 2019 and the reserves for the implementation of the study in 2010 .

Soil analysis was carried out at the Soil-Water-Plant laboratory at the Farako Bâ research center. The $\mathrm{pH}$ water was determined with $\mathrm{pH}$-meter with glass electrode following a 1/2.5 solution ratio. [14] Method was used for organic carbon determination. The organic matter rate is obtained from the formula Carbon rate * 1.724. Total nitrogen was measured by the Kjeldahl method [15]. Total Phosphorus was measured on the condensed mineralization [16]. Assimilable phosphorus was determined by the BRAY 1 method [17]. Total potassium was measured at the flame spectro-photometer from the remnant of the filter from the mineralization of soil test shots.

Data were collected and entered with the Excel 2010 version. XLSTAT 2016 with Fisher test (5\%) was used for means separating and standard deviations was calculated with $\mathrm{R}$ version 3.6.0 (2019-04-26). 


\section{Results}

\subsection{Variations of the Yields of Maize Associated to Cover Crops}

Cover crops associated with maize give equivalent maize yields compared to Conventional Tillage (Table 1). The DMC allows an equivalent yield of maize compared to Conventional Tillage and Direct Seeding. Over five years of maize production in rotation with cotton, the average yields ranged from $2791 \mathrm{~kg} \cdot \mathrm{ha}^{-1}(\mathrm{DMC} / B$. ruziziensis $+M$. cochinchinensis) to $3221 \mathrm{~kg} \cdot \mathrm{ha}^{-1}$ (Conventional Tillage). Maize yields increased regardless of treatments (Table 1).

\subsection{Variations of Cotton Yields in Systems of Production}

Statistical analyses indicate that cotton yields from 2011 to 2019 were not influenced by the treatments applied (Table 2). Compared to Conventional Tillage, DMC did not give significant improvements in cotton yields. Over the five years of cotton production in rotation, average yields ranged from $1191 \mathrm{~kg} \cdot \mathrm{ha}^{-1}$ (DMC/B. ruziziensis) to $1390 \mathrm{~kg} \cdot \mathrm{ha}^{-1}$ (Conventional Tillage). Overall, trends indicate stability in cotton yields with Conventional Tillage compared to the Direct Seeding and DMC that decline slightly.

Table 1. Evolution of the maize yields from 2010 to 2018 under different treatments.

\begin{tabular}{ccccccc}
\hline & 2010 & 2012 & 2014 & 2016 & 2018 & Average \\
\cline { 2 - 7 } Treatments & \multicolumn{5}{c}{$\mathrm{kg} \cdot \mathrm{ha} \mathrm{a}^{-1}$} \\
\hline Conv. Tillage & $2368 \pm 448$ & $2408 \pm 444$ & $3921 \pm 180$ & $3339 \pm 133$ & $4065 \pm 105$ & $3221 \pm 185$ \\
Direct Seeding & $1938 \pm 305$ & $2026 \pm 449$ & $3875 \pm 165$ & $3004 \pm 790$ & $3649 \pm 285$ & $2897 \pm 300$ \\
DMC/ B. ruz. & $2120 \pm 205$ & $2213 \pm 382$ & $3775 \pm 286$ & $3289 \pm 433$ & $3336 \pm 326$ & $2945 \pm 265$ \\
DMC/B. ruz. + Muc. & $2071 \pm 346$ & $2302 \pm 396$ & $3800 \pm 202$ & $2604 \pm 381$ & $3172 \pm 255$ & $2791 \pm 168$ \\
DMC/C. juncea & $2197 \pm 417$ & $2325 \pm 509$ & $4107 \pm 56$ & $3298 \pm 530$ & $3269 \pm 371$ & $3039 \pm 286$ \\
F & 0.263 & 0.110 & 0.467 & 0.384 & 1.643 & 0.431 \\
Probability (0.05) & 0.897 (ns) & 0.977 (ns) & 0.759 (ns) & 0.817 (ns) & 0.215 (ns) & 0.784 (ns) \\
\hline
\end{tabular}

ns: not significant. DMC: Direct sowing under mulch-based cropping system.

Table 2. Evolution of cotton yields from 2011 to 2019 under different treatments.

\begin{tabular}{ccccccc}
\hline & 2011 & 2013 & 2015 & 2017 & 2019 & Average \\
\cline { 2 - 7 } Treatments & & \multicolumn{5}{c}{$\mathrm{kg} \cdot \mathrm{ha}^{-1}$} \\
Conv. Tillage & $1361 \pm 152$ & $1415 \pm 187$ & $1437 \pm 211$ & $1165 \pm 113$ & $1516 \pm 75$ & $1390 \pm 76$ \\
Direct Seeding & $1673 \pm 101$ & $1246 \pm 203$ & $986 \pm 87$ & $975 \pm 26$ & $1207 \pm 284$ & $1218 \pm 115$ \\
DMC/B. ruz. & $1302 \pm 86$ & $1204 \pm 125$ & $1281 \pm 184$ & $985 \pm 22$ & $1184 \pm 113$ & $1191 \pm 86$ \\
DMC/B. ruz. + Muc. & $1322 \pm 189$ & $1439 \pm 29$ & $1131 \pm 152$ & $1132 \pm 58$ & $1205 \pm 124$ & $1250 \pm 89$ \\
DMC/C. juncea & $1514 \pm 135$ & $1293 \pm 42$ & $1007 \pm 82$ & $1159 \pm 55$ & $1135 \pm 104$ & $1230 \pm 65$ \\
F & 1.300 & 0.566 & 1.558 & 2.107 & 0.910 & 0.715 \\
Probability (0.05) & 0.314 (ns) & 0.691 (ns) & 0.236 (ns) & 0.131 (ns) & 0.483 (ns) & 0.594 (ns) \\
\hline
\end{tabular}

ns: non-significant. DMC: Direct sowing under mulch-based cropping system. 


\subsection{Effects of Direct Sowing under Mulch-Based Cropping System Biomass Production}

The average biomass production of maize and total (maize + covers crops) was affected by the compared treatments (Table 3 ). The maize biomass production varied between $4210 \mathrm{~kg} \cdot \mathrm{ha}^{-1}(\mathrm{DMC} /$ B. ruziziensis + M. cochinchinensis $)$ and 5497 $\mathrm{kg} \cdot \mathrm{ha}^{-1}$ (Conventional Tillage) in average (Table 3 ). The best maize biomass production was obtained with Conventional Tillage. The DMC allows increasing the total biomass compared to Conventional Tillage. The average of total biomass varied between $4746 \mathrm{~kg} \cdot \mathrm{ha}^{-1}$ (Direct Seeding) and $7413 \mathrm{~kg} \cdot \mathrm{ha}^{-1}(\mathrm{DMC} / B$. ruziziensis $+M$. cochinchinensis). The use of cover plants increased total biomass production. In average, the association of $B$. ruziziensis, $B$. ruziziensis $+M$. cochinchinensis and $C$. juncea contribute to significantly increase the total biomass. A better total biomass production was observed with the association of $B$. ruziziensis + M. cochinchinensis cropping with maize (Table 3).

\subsection{Effects of 10 Years of Direct Sowing under Mulch-Based Cropping System on Soil Chemicals Characteristics}

\section{Effects of direct sowing under mulch-based cropping system on soil pH}

After 10 years of maize associated to cover crops in rotation with cotton, a little variation in the $\mathrm{pH}$ water was observed. The $\mathrm{pH}$ was between $5.54(\mathrm{DMC} / C$. juncea mulch) and 5.69 (Direct seeding). With the Conventional Tillage the $\mathrm{pH}$ was 5.60 and 5.62 with $\mathrm{DMC} /$ B. ruziziensis mulch and 5.63 with DMC/B. ruziziensis + M. cochinchinensis mulch. Compared to the Conventional Tillage, Direct Seeding and DMC did not cause a significant change of soil $\mathrm{pH}$.

Table 3. Biomass production by maize straws and cover crops $\left(\mathrm{kg} \cdot \mathrm{ha} \mathrm{H}^{-1}\right)$ from 2010 to 2018 under different treatments.

\begin{tabular}{|c|c|c|c|c|c|c|c|c|}
\hline \multicolumn{2}{|c|}{ Treatments } & $\begin{array}{l}\text { Conv. } \\
\text { Tillage }\end{array}$ & $\begin{array}{l}\text { Direct } \\
\text { Sowing }\end{array}$ & $\begin{array}{c}\mathrm{DMC} / B . \\
\mathrm{ruz}\end{array}$ & $\begin{array}{c}\mathrm{DMC} / B . \\
r u z+M . \text { coch. }\end{array}$ & $\begin{array}{c}\mathrm{DMC} / C . \\
\text { Juncea }\end{array}$ & $\mathrm{F}$ & $\begin{array}{c}\mathrm{P} \\
(0.05)\end{array}$ \\
\hline \multirow{2}{*}{2010} & Maize straw & $5444 \mathrm{a}$ & $4786 \mathrm{a}$ & $4684 \mathrm{a}$ & $4257 \mathrm{a}$ & $4467 \mathrm{a}$ & 2.023 & 0.150 (ns) \\
\hline & Cover crops & - & - & $2450 \mathrm{a}$ & $2751 \mathrm{a}$ & $1616 \mathrm{~b}$ & 8.577 & $0.010(\mathrm{~s})$ \\
\hline \multirow{2}{*}{2012} & Maize straw & $5230 \mathrm{a}$ & 4948 a & $5148 \mathrm{a}$ & $4443 \mathrm{a}$ & $4473 \mathrm{a}$ & 0.329 & 0.854 (ns) \\
\hline & Cover crops & - & - & $1788 \mathrm{a}$ & $1196 \mathrm{a}$ & $1497 \mathrm{a}$ & 1.369 & 0.308 (ns) \\
\hline \multirow{2}{*}{2014} & Maize straw & $6510 \mathrm{a}$ & 5729 a & $5313 \mathrm{a}$ & $5104 \mathrm{a}$ & $5260 \mathrm{a}$ & 2.688 & 0.078 (ns) \\
\hline & Cover crops & - & - & 3917 a & $2733 \mathrm{~b}$ & $1433 c$ & 33.889 & $0.000(\mathrm{~s})$ \\
\hline \multirow{2}{*}{2016} & Maize straw & $5136 \mathrm{a}$ & $4157 \mathrm{ab}$ & $3755 \mathrm{~b}$ & $3022 \mathrm{~b}$ & $3788 \mathrm{~b}$ & 3.801 & $0.029(\mathrm{~s})$ \\
\hline & Cover crops & - & - & $2481 \mathrm{a}$ & $3521 \mathrm{a}$ & 2009 a & 2.322 & 0.160 (ns) \\
\hline \multirow{2}{*}{2018} & Maize straw & $4897 \mathrm{a}$ & $4311 \mathrm{a}$ & $4522 \mathrm{a}$ & $4458 \mathrm{a}$ & $4347 \mathrm{a}$ & 0.433 & $0.782(\mathrm{~ns})$ \\
\hline & Cover crops & - & - & $2695 \mathrm{ab}$ & $3808 \mathrm{a}$ & $1712 \mathrm{~b}$ & 9.112 & $0.009(\mathrm{~s})$ \\
\hline \multirow{2}{*}{ Average } & Maize straw & $5497 \mathrm{a}$ & $4746 \mathrm{ab}$ & $4568 \mathrm{~b}$ & $4210 \mathrm{~b}$ & $4466 \mathrm{~b}$ & 3.425 & $0.040(\mathrm{~s})$ \\
\hline & Cover crops & - & - & $2666 \mathrm{a}$ & $2802 \mathrm{a}$ & $1654 \mathrm{~b}$ & 14.435 & $0.002(\mathrm{~s})$ \\
\hline
\end{tabular}

DMC: Direct sowing under mulch-based cropping system. 
Effects of direct sowing under mulch-based cropping system on soil organic matter

Statistical analysis shows no significant difference $(\mathrm{P}>0.05 \%)$ between treatments regardless of the different soil layers (Figure 2). Soil organic matter increase with Direct Seeding and Direct sowing under mulch-based cropping system (DMC) compared to Conventional Tillage. In 10 years on $0-5 \mathrm{~cm}$ depth, $\mathrm{DMC} /$ B. ruziziensis, $\mathrm{DMC} /$ B. ruziziensis $+M$. cochinchinensis and DMC/C. juncea gave respectively $27 \%, 34 \%$ and $38 \%$ improvement of organic matter compared to Conventional Tillage. Direct Seeding without cover plants gave 33\% increase of organic matter compared to Conventional Tillage. On $5-10 \mathrm{~cm}$ depth, compared to Conventional Tillage, the soil organic matter content improvement was $5 \%, 14 \%$ and $17 \%$ respectively with Direct Seeding, $\mathrm{DMC} /$ B. ruziziensis + $M$. cochinchinensis and DMC/C. juncea. On $10-20 \mathrm{~cm}$ depth, only DMC showed increases of soil organic matter content.

These increases were in order of 23\% (DMC/B. ruziziensis) and 9\% (DMC/B. ruziziensis $+M$. cochinchinensis and $\mathrm{DMC} / C$. juncea) compared to Conventional Tillage. High soil organic matter was observed with $C$. juncea use as a cover crop on the $0-5 \mathrm{~cm}$ and $5-10 \mathrm{~cm}$ depth and with DMC/B. ruziziensis on the $10-20$ $\mathrm{cm}$ depth. The organic matter content of soil follows a gradient from the upper $(0-5 \mathrm{~cm})$ to the deep depth $(5-10 \mathrm{~cm}$ and $10-20 \mathrm{~cm})$.

\section{$>$ Effects of direct sowing under mulch-based cropping system on nitrogen ( $\mathrm{N}$ total)}

The analyses showed $\mathrm{N}$ total is equivalent on the different depth and follow a gradient from the upper to the deep depth (Figure 3). Compared to Conventional Tillage, Direct Seeding and DMC have improved total N. These increases are $21 \%$ and $3 \%$ respectively on the $0-5 \mathrm{~cm}$ and $5-10 \mathrm{~cm}$ depth with Direct Seeding compared to Conventional Tillage. With DMC systems increases over Conventional Tillage were in the range of $15 \%$ to $29 \%$ on the $0-5 \mathrm{~cm}$ depth, $0 \%$ to $9 \%$ on the $5-10 \mathrm{~cm}$ depth and $4 \%$ to $19 \%$ on the $10-20 \mathrm{~cm}$ depth. In the DMC systems, the best total $\mathrm{N}$ content were observed with treatments containing leguminous as $M$. cochinchinensis and $C$. juncea.

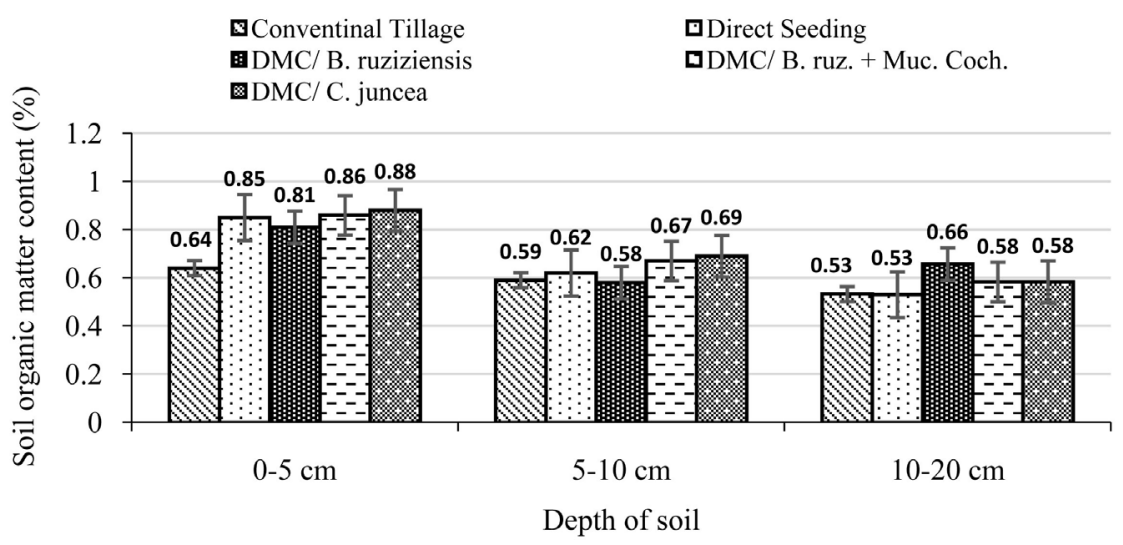

Figure 2. Effects of treatments on soil organic matter (\%) in 2019. 


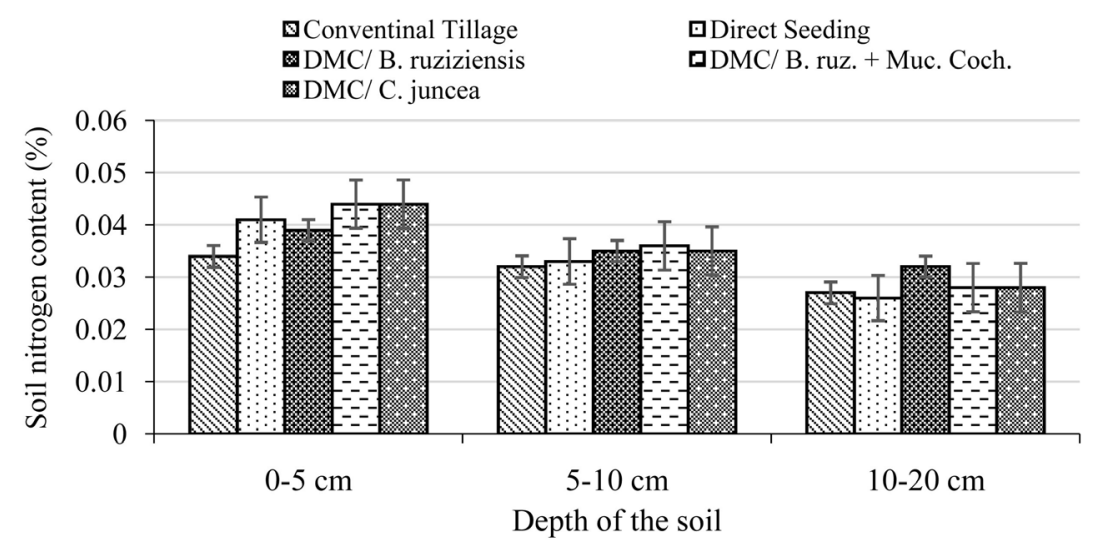

Figure 3. Effects of treatments on soil nitrogen content (\%) in 2019.

Effects of direct sowing under mulch-based cropping system on $\mathrm{P}$ total, $\mathrm{P}$ assimilable, $\mathrm{K}$ total and $\mathrm{K}$ available

The analyses of variance revealed no significant differences between DMC, Direct Seeding and Conventional Tillage for $\mathrm{P}$ total and $\mathrm{P}$ assimilable levels regardless of soil depth (Table 4). On the $0-5 \mathrm{~cm}, 5-10 \mathrm{~cm}$ and $10-20 \mathrm{~cm}$ depth, Conventional Tillage gave higher total $\mathrm{P}$ than those of Direct Seeding and DMC. On other hand, we notice on $0-5 \mathrm{~cm}$ depth, high levels of assimilable $\mathrm{P}$ with $\mathrm{DMC} /$ B. ruziziensis $+M$. Cochinchinensis and DMC/C. juncea. On the $0-5 \mathrm{~cm}$, $5-10 \mathrm{~cm}$ and $10-20 \mathrm{~cm}$ depth considered, total $\mathrm{K}$ and available $\mathrm{K}$ were statistically equivalent. On $0-5 \mathrm{~cm}$, availability $\mathrm{K}$ was improved with Direct Seeding and DMC system compared to Conventional Tillage (Table 5).

Soil chemicals characteristics reviews over 10 years of operation (0 - 5 $\mathrm{cm}$ )

Over 10 years of crop rotations (maize-cotton) the $\mathrm{pH}$ of soil has changed slightly, depending on the treatments (Figure 4(a)). Soil $\mathrm{pH}$ balances variation between 2010 and 2019 indicate a decrease of $\mathrm{pH}$ on the upper depth $(0-5 \mathrm{~cm})$ with Conventional Tillage as well as Direct Seeding alone and DMC/B. ruziziensis and $\mathrm{DMC} / B$. ruziziensis $+M$. cochinchinensis. $\mathrm{pH}$ balance was from -0.055 to -02 units. On the other hand, with $C$. juncea use as a cover crop in the DMC system, the soil acidity balance shows an increase of one unit towards neutrality.

As for organic matter contents, only DMC/B. ruziziensis associated with $M$. cochinchinensis and $\mathrm{DMC} / C$. juncea provided stability or a little increase of $+0.054 \%(\mathrm{DMC} /$ B. ruziziensis + M. cochinchinensis $)$ and $+0.90 \%(\mathrm{DMC} / C$. juncea) (Figure 4(b)).

The total $\mathrm{N}$ decreased with Conventional Tillage, Direct Seeding and $\mathrm{DMC} / B$. ruziziensis, $D M C / B$. ruziziensis $+M$. cochinchinensis and DMC/C. juncea. Leguminous cover crops use ( $M$. cochinchinensis and $C$. juncea) did not give nitrogen positive balance. Total $\mathrm{P}$ balance show $11.53 ; 12.54$ and $37.91 \mathrm{mg} \cdot \mathrm{kg}^{-1}$ improvements respectively with $\mathrm{DMC} / \mathrm{B}$. ruziziensis, $\mathrm{DMC} / C$. juncea and Conventional Tillage. However, total $\mathrm{P}$ improvements were not inducing any improvement of availability $\mathrm{P}$ (Figure $4(\mathrm{c})$ ). 


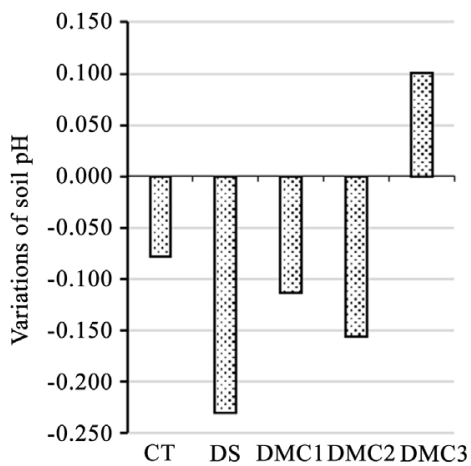

(a)
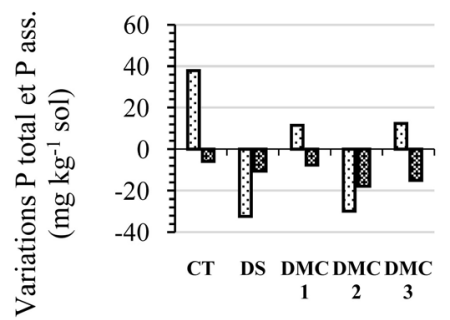

Traitements

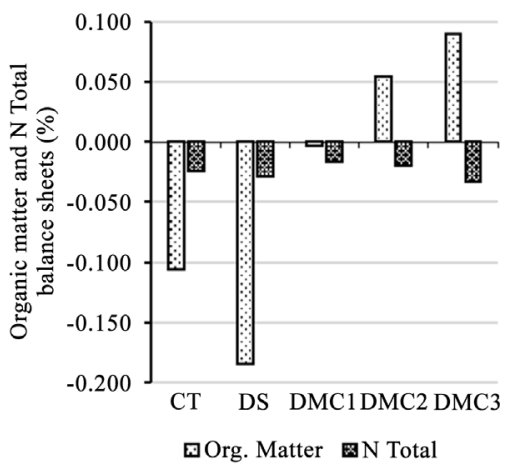

(b)

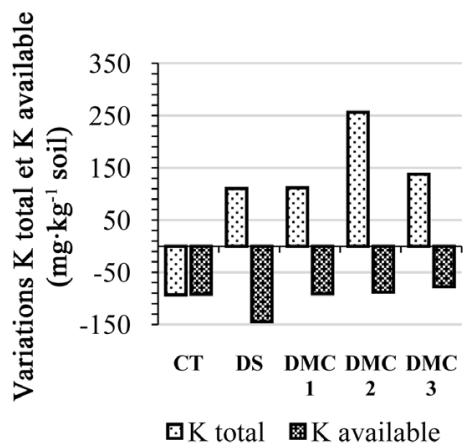

(d)

Figure 4. Soil chemicals characteristics from 2010 to 2019. Legend: CT: Conventional Tillage; DS: Direct Seeding; DMC 1: DMC/B. ruziziensis; DMC 2: DMC/B. ruziziensis + M. cochinchinensis, DMC 3: DMC/C. juncea. (a) Soil pH balance $(0-5 \mathrm{~cm})$; (b) Organic matter and $\mathrm{N}$ Total balance $(0-5 \mathrm{~cm})$; (c) P Total and P ass balance sheets. $(0-5 \mathrm{~cm})$; (d) $\mathrm{K}$ Total and $\mathrm{K}$ available balance $(0-5 \mathrm{~cm})$.

Table 4. Effects of treatments on total P and assimilable P in soil (2019).

\begin{tabular}{ccccccc}
\hline & \multicolumn{2}{c}{$0-5 \mathrm{~cm}$} & \multicolumn{2}{c}{$5-10 \mathrm{~cm}$} & $10-20 \mathrm{~cm}$ \\
\cline { 2 - 7 } Treatments & P total & P ass. & P total & P ass. & P total & P ass. \\
\cline { 2 - 7 } & & & mg.kg-1 of soil & & \\
& & & $154.61 \pm 36$ & $11.91 \pm 2$ & $144.61 \pm 34$ & $7.27 \pm 1$ \\
Conv. tillage & $150.94 \pm 34$ & $12.17 \pm 4$ & $154 \pm 10 \pm 1$ \\
Direct Sowing & $101.15 \pm 11$ & $12.01 \pm 2$ & $98.45 \pm 4$ & $10.49 \pm 3$ & $120.86 \pm 30$ & $7.10 \pm 1$ \\
DMC/B. ruz. & $124.17 \pm 29$ & $10.88 \pm 1$ & $120.86 \pm 27$ & $5.13 \pm 1$ & $119.11 \pm 26$ & $5.43 \pm 1$ \\
DMC/B. ruz.+ Muc. & $104.68 \pm 10$ & $14.43 \pm 4$ & $92.88 \pm 5$ & $9.81 \pm 2$ & $100.18 \pm 9$ & $6.21 \pm 1$ \\
DMC/C. juncea & $135.44 \pm 28$ & $14.66 \pm 2$ & $127.46 \pm 34$ & $9.14 \pm 2$ & $117.46 \pm 30$ & $5.57 \pm 1$ \\
F & 0.736 & 0.315 & 0.959 & 1.678 & 0.34 & 0.51
\end{tabular}

DMC: Direct sowing under mulch-based cropping system.

Total $\mathrm{K}$ balances indicate improvements with Direct Seeding, DMC/B. ruziziensis, $\mathrm{DMC} / B$. ruziziensis $+M$. cochinchinensis and DMC/C. juncea compared to Conventional Tillage. These total $\mathrm{K}$ positives balances did not induce an improvement of his availability in soil (Figure $4(\mathrm{~d})$ ). 
Table 5. Effects of treatments on total K and available K in soil (2019).

\begin{tabular}{ccccccc}
\hline & \multicolumn{2}{c}{$0-5 \mathrm{~cm}$} & \multicolumn{2}{c}{$5-10 \mathrm{~cm}$} & \multicolumn{2}{c}{$10-20 \mathrm{~cm}$} \\
\cline { 2 - 7 } Treatments & K total & K available. & K total & K available. & K total & K available. \\
\cline { 2 - 7 } & \multicolumn{5}{c}{$\mathrm{mg} \cdot \mathrm{kg}^{-1}$ of soil } \\
\hline Conv. tillage & $1988 \pm 273$ & $89 \pm 12$ & $1733 \pm 160$ & $99 \pm 4$ & $2002 \pm 194$ & $75 \pm 2$ \\
Direct Sowing & $1867 \pm 139$ & $131 \pm 21$ & $1878 \pm 200$ & $103 \pm 3$ & $2050 \pm 191$ & $77 \pm 9$ \\
DMC/B. ruz. & $1685 \pm 99$ & $146 \pm 9$ & $2090 \pm 328$ & $82 \pm 1$ & $1990 \pm 113$ & $70 \pm 2$ \\
DMC/B. ruz. + Muc. & $1966 \pm 332$ & $128 \pm 14$ & $1976 \pm 284$ & $1001 \pm 2$ & $1733 \pm 134$ & $68 \pm 6$ \\
DMC/C. juncea & $1709 \pm 64$ & $141 \pm 20$ & $1736 \pm 91$ & $82 \pm 3$ & $2076 \pm 162$ & $69 \pm 3$ \\
F & 0.458 & 1.982 & 0.455 & 0.31 & 0.718 & 0.637 \\
P (0.05) & $0.766(\mathrm{~ns})$ & $0.149(\mathrm{~ns})$ & 0.767 (ns) & 0.867 (ns) & $0.593(\mathrm{~ns})$ & $0.644(\mathrm{~ns})$ \\
\hline
\end{tabular}

DMC: Direct sowing under mulch-based cropping system.

\section{Discussion}

During the 10 years of crop rotation, the effect of direct Seeding with or without a cover plant on cotton and maize yields of Direct Seeding was statistically equivalent to conventional tillage. The use of B. ruziziensis, B. ruziziensis $+M$. cochinchinensis and $C$. juncea as cover crops associated with maize did not influence the maize yields. After 10 years cultivation, including 5 years of cotton cultivation, the cotton yields indicate that Direct Seeding, direct sowing under mulchbased cropping system were equivalent to Conventional Tillage. These results confirm [9] [10] [18] who found an equivalence between Direct Seeding and Conventional Tillage after 5 years or 20 years of direct sowing under mulchbased cropping system. Biomass production has been significantly improved by cover crops. This ensured fairly good soil coverage during direct seeding in a mulch-based cropping system. [19] estimated that with DMC, biomass production of at least $6000 \mathrm{~kg} \cdot \mathrm{ha}^{-1}$ are required to ensure good soil cover and according to [3], $2 \mathrm{t} \cdot \mathrm{ha}^{-1}$ of biomass are required to improve soil water balances compared to Conventional Tillage. B. ruziziensis has ensured high of biomass and amount better when associated with $M$. Cochinchinensis. The contribution of $C$. junceabiomass productionwas lower than B. ruziziensis and B. ruziziensis with $M$. cochinchinensis.

With the DMC, soil acidity varied very little compared to Direct Seeding and Conventional Tillage. The balance sheets indicate general decline of $\mathrm{pH}$ with the Conventional Tillage, Direct Seeding and DMC/B. ruziziensis, DMC/B. ruziziensis $+M$. cochinchinensis. With $C$. juncea as a cover crop in DMC, the increase of $\mathrm{pH}$ to neutral $\mathrm{pH}$ has been observed.

In 2019, organic matter was relatively higher with DMC tested compared to Direct Seeding without cover crop and Conventional Tillage on $0-5 \mathrm{~cm}$ and $10-$ $20 \mathrm{~cm}$ depth. The increasing of organic matter with DMC is attributed to cover crops degradation. These results confirm studies of [4] [20] that obtained same trends in tropical climate conditions. The accumulation of organic matter in the 
$0-5 \mathrm{~cm}$ depth compared to the $5-10 \mathrm{~cm}$ and $10-20 \mathrm{~cm}$ depth is due to more pronounced accumulation and degrading in the tropical area of residues and a higher root density in this depth. Conventional Tillage contributes to create conditions for a rapid decomposition of soil organic matter. The higher organic matter was recorded with the use of $C$. juncea as a cover crop because the decomposition of $C$. juncea residue was slow compared to B. ruziziensis and $M$. cochinchinensis residues. The contribution of leguminous cover crops was only in the first 10 centimeters of soil depth. The leguminous used as cover crops, namely $M$. cochinchinensis and $C$. juncea, has led to increases soil nitrogen content, particularly on the $0-5 \mathrm{~cm}$ and $5-10 \mathrm{~cm}$ depth. This is related to the atmospheric nitrogen-fixing characteristics of leguminous cover crops used. These results are similar to those of [21] which featured leguminous cover crops with a strong root system that could improve nitrogen levels on different depth of soil. B. ruziziensis, which has a powerful root system fasciculate in association with M. cochinchinensis, has contributed to better colonization of depth through its important and fasciculate root system that can reach in deep depth. The high levels of total $\mathrm{P}$ and assimilable $\mathrm{P}$ with Conventional Tillage are partly related to the faster of organic matter degrading in tropical climate area. Conventional Tillage creates the conditions for substrate mineralization by soil micro-organisms. The results of [22] indicate a significant reduction in organic matter under continuous ploughing related to the mineralization process.

\section{Conclusion}

Cover cropping systems are effective because they ensure stability and durability of crop production. Frequent ploughing is not the same solution, especially under conditions of climate change that prevent good crop establishment. Soil acidity under both conventional tillage and DMC systems showed little variation. The DMC systems improved total soil $\mathrm{K}$ levels while reducing available $\mathrm{K}$ losses. B. ruziziensis, alone or in combination with $M$. cochinchinensis and $C$. juncea, contributed effectively to biomass production. These cover crops have stabilized or improved soil organic matter levels. These cover crops have stabilized or improved soil organic matter levels. The contribution of the leguminous $(M$. cochinchinensis and $C$. juncea) was weakly perceived on the soil nitrogen content in the upper layers. DMC appears to be an applicable practice in cotton-based production systems in the southern Sudanese zone of Burkina Faso. However, its adoption requires a slight adaptation of the production method. B. ruziziensis alone or in combination with $M$. cochinchinensis ensures good biomass production. The adoption of DMC requires support from the government and open collaboration between the actors concerned such as producers, breeders and local authorities.

\section{Acknowledgements}

The authors express their gratitude to Cotton $4+$ Togo Project and the In- 
ter-professional Cotton Association in Burkina Faso (AICB) for funding this study.

\section{Conflicts of Interest}

The authors declare no conflicts of interest regarding the publication of this paper.

\section{References}

[1] Coulibaly, K., Vall, E., Naudin, K., Nacro, H.B. and Havard, M. (2018) Effets du travail minimum du sol en sec sur la flexibilité du calendrier agricole et le rendement du maïs en zone soudanienne du Burkina Faso. Tropicultura, 36, 608-620.

[2] Agence Française de Développement (2006) Le semis sous couverture végétale permanente (SCV). Paris, $68 \mathrm{p}$.

[3] Ouattara, B., Coulibaly, K., Kohio, E., Doumbia, S., Ouédraogo, S. and Nacro, H.B. (2018) Effets du Système de Culture sous couverture Végétale (SCV) sur les flux hydriques d'un sol ferrugineux à l'Ouest du Burkina Faso. International Journal of Biological and Chemical Sciences, 12, 1770-1783.

https://doi.org/10.4314/ijbcs.v12i4.20

[4] Yadav, M.R., Parihar, C.M., Kumar, R., Yadav, R.K., Jat, S.L., Singh, A.K., Ram, H., Meena, R.K., Singh, M., Meena, V.K., Yadav, N., Yadav, B., Kumawat, C. and Jat, M.L. (2017) Conservation Agriculture and Soil Quality-An Overview. International Journal of Current Microbiology and Applied Sciences, 6, 707-734. https://doi.org/10.20546/ijcmas.2017.602.080

[5] Corsi, S. and Muminjanov, H. (2019) Conservation Agriculture: Training Guide for Extension Agents and Farmers in Eastern Europe and Central Asia. FAO, Rome, 140 p.

[6] Bado, B.V. (2002) Rôle des légumineuses sur la fertilité des sols ferrugineux tropicaux des zones guinéenne et soudanienne du Burkina Faso. Thèse de doctorat, Université Laval, Québec, 197.

[7] Coulibaly, K., Vall, E., Autfray, P., Nacro, H.B. and Sedogo, P.M. (2012) Effets de la culture permanente coton-maïs sur l'évolution d'indicateurs de fertilité des sols de l'Ouest du Burkina Faso. International Journal of Biological and Chemical Sciences, 6, 1069-1080. https://doi.org/10.4314/ijbcs.v6i3.13

[8] Doamba, S.M.F., Nacro, H.B., Sanon, A. and Sedogo, P.M. (2011) Effet des cordons pierreux sur l'activité biologique d'un sol ferrugineux tropical lessivé (Province du Kouritenga au Burkina Faso). International Journal of Biological and Chemical Sciences, 5, 304-313. https://doi.org/10.4314/ijbcs.v5i1.68106

[9] Koulibaly, B., Ouattara, A., Dakuo, D., Ouattara, K., Traoré, O., Geraldo, J.D. and Lompo, F. (2017) Efficacy of the Association of Cover Crops with Maize and Direct Sowing Short-Term Effect on Crops Yield in Maize-Cotton Cropping System in Wester Burkina Faso. African Journal of Agricultural Research, 12, 3577-3584.

[10] Diakahté, D., Chopart, J.L. and Ralisch, R. (2018) Traits fonctionnels de Brachiaria (Trin.) brizantha (Hochst.) Stapf, B. decumbens Stapf et B. ruziziensis (Germ. \& Evrard) ndab cultives en association avec Pennisetum glaucum (L.) Leeke R. br. en climat tropical sec. Agronomie Africaine, 30, 225-235.

[11] Gamour, G., Dorel, M., Toc Hoa Quoc, Meynard, C. and Risede, J.M. (2014) A Trait-Based Characterization of Cover Plants to Assess Their Potential to Provide a Set of Ecological Services in Banana Cropping Systems. European Journal of Agronomy, 
52, 218-228. https://doi.org/10.1016/j.eja.2013.09.004

[12] Gama-Rodrigues, A.C., Gama-Rodrigues, E.F. and Brito, E.C. (2007) Decomposition and Nutrient Release from Cover Crop Residues in Passion-Fruit Plantation. Revista Brasileira de Ciência do Solo, 31, 1421-1428. https://doi.org/10.1590/S0100-06832007000600019

[13] Husson, O., Charpentier, H., Razanamparany, C., Moussa, N., Michellon, R., Naudin, K., Razafintsalama, H., Rakotoarinivo, C. and Rakotondramanana, S.L. (2008) Fiches techniques plantes de couverture: Graminées pérennes (Brachiaria sp.). Manuel pratique du semis direct à Madagascar. Volume III. Chapitre 3. \$4.1. 20 p.

[14] Walkley, A. and Black, R.N. (1934) An Examination of the Method Degtjareff for Determining Soil Organic Matter and to Proposed Modification of the Chromic Acid Titration Method. Soil Science, 37, 29-38. https://doi.org/10.1097/00010694-193401000-00003

[15] Hillebrand, W.F., Lundell, G.E.F., Bright, H.A. and Hoffman, J.I. (1953) Applied Inorganic Analysis. John Wiley \& Sons Inc., New York, 1034.

[16] Anderson, J.M. and Ingram, J.S. (1989) Tropical Soil Biology. Handbook of Methods. CAB International, Wallingford, $117 \mathrm{p}$.

[17] Dickman, S.R. and Bray, H.R. (1940) Colorimetric Determination of Phosphate. Industrial \& Engineering Chemistry Analytical Edition, 12, 665-668. https://doi.org/10.1021/ac50151a013

[18] Chervet, A., Ramseier, L., Sturny, W.G., Zuber, M., Stettler, M., Weisskopf, P., Zihlmann, U., Martínez, G.I. and Keller, T. (2016) Rendements et paramètres du sol après 20 ans de semis direct et de labour. Recherche Agronomique Suisse, 7, 216-223.

[19] Nunes, U.R., Andrade Júnior, V.C., Silva, E.B., Santos, N.F., Costa, H.A.O. and Ferreira, C.A. (2006) Covering Crops Straw Production and Common Bean Productivity in No-Tillage System. Pesquisa Agropecuaria Brasileira, 41, 943-948.

[20] Razafimbelo, T.M., Albrecht, A., Basile, I., Borschneck, D., Bourgeon, G., Feller, C., Ferrer, H., Michellon, R., Moussa, N., Muller, B., Razanamparany, C., Seguy, L., Swarc, M. and Oliver, R. (2006) Effet de différents systèmes de culture à couverture végétale sur le stockage du carbone dans un sol argileux des Hautes Terres de Madagascar. Étude et Gestion des Sols, 13, 113-127.

[21] Rakotoarisoa, J., Oliver, R., Dusserre, J., Muller, B., Douzet, J.M., Michellon, R., Moussa, N., Razafinjara, L.A., Rajeriarison, C. and Scopel, E. (2010) Bilan de l'azote minéral au cours du cycle du riz pluvial sous-systèmes de culture en semis direct sous couverture végétale en sol ferrallitique argileux à Madagascar. Etude et Gestion des Sols, 17, 169-186.

[22] Bottinelli, N. (2010) Evolution de la structure et de la perméabilité d'un sol en contexte de non labour associé à l'apport d'effluent d'élevage: Rôle de l'activité lombricienne. Sciences de la Terre. Agrocampus-Ecole nationale supérieure d'agronomie de rennes, 2010. 165 p. 